\title{
Analisis efisiensi pengeluaran kesehatan provinsi jambi
}

\author{
Muhammad Fajri ${ }^{1}$, Rinda Siaga $\mathbf{P}^{\mathbf{2}}$ \\ Universitas Islam “45” Bekasi, Jawa Barat. \\ Email:muhammadfajeriii16@gmail.com
}

\begin{abstract}
Abstrak
Provinsi Jambi merupakan provinsi yang sedang berkembang di Sumatera. Namun, pertumbuhan yang tinggi didominasi dari sisi konsumsi. Hal ini berpengaruh terhadap alokasi belanja kesehatan yang merupakan bagian dari sisi pengeluaran pemerintah. Hal tersebut dapat mempengaruhi kualitas kesehatan di daerah yang fasilitas kurang memadai. Terjadi ketidakmerataan fasilitas kesehatan di Kabupaten/Kota di Provinsi Jambi. Tujuan pertama adalah untuk memperkirakan skor efisiensi teknis pengeluaran kesehatan Kabupaten/Kota di Provinsi Jambi. Tujuan kedua adalah menganalisis faktor lingkungan yang memiliki peran penting dalam mempengaruhi skor efisiensi teknis Kabupaten/Kota di Provinsi Jambi. Penelitian ini menghitung skor efisiensi teknis menggunakan metode Data Envelopment Analysis (DEA) dan menggunakan metode Tobit untuk analisis faktor lingkungan. Studi ini menghitung skor efisiensi teknis dari pengeluaran kesehatan di 9 Kabupaten dan 2 Kota di Provinsi Jambi dari 2011 hingga 2016.
\end{abstract}

Kata Kunci: Pengeluaran kesehatan; data envelopment analysis; tobit

\section{Analysis of the efficiency of health spending in the province of jambi}

\begin{abstract}
Jambi Province is the developing region in Sumatera. However, the high growth is dominated by consumption side. The indicates affect on the allocation of health spending which is part of government expenditure side. This can affect the quality of health in areas with weak facilities. Inequality of health facilities occurred in regencies/cities in Jambi Province. The first objective is to estimate scores of technical efficiency of health spending of regencies/cities in Jambi Province. The second is to analyze the environmental factors that have an important role in effect on the technical efficiency scores of regencies/cities in Jambi Province. This research calculates scores of technical efficiency using Data Envelopment Analysis (DEA) method and use the Tobit method for the analysis of environmental factors. This study calculates the technical efficiency scores of health spending in 9 districts and 2 cities in Jambi Province from 2011 to 2015
\end{abstract}

Keywords: Health spending; data envelopment analysis; tobit 


\section{PENDAHULUAN}

Provinsi Jambi merupakan salah satu provinsi yang sedang berkembang di Pulau Sumatera. Hal ini ditandai dengan pertumbuhan ekonomi sebesar 4.1 persen di tahun 2015 dan 2016 (Badan Pusat Statistik, 2018). Namun, dilihat dari sisi pengeluaran PDRB tahun 2016, kontribusi terbesar disumbangkan oleh konsumsi sebesar 44.7 persen, sedangkan sektor pemerintah hanya menyumbang sebesar 7.2 persen (Badan Pusat Statistik, 2018). Indikasi tersebut menjelaskan bahwa pertumbuhan ekonomi Jambi lebih banyak disumbangkan oleh konsumsi dibandingkan belanja pemerintah.

Dilihat dari sektor pemerintah pengeluaran belanja Provinsi Jambi di tahun 2017 sebesar 4.3 Triliun. Berdasarkan jumlah tersebut alokasi belanja kesehatan Provinsi Jambi sebesar 11 persen. Sesuai dengan Undang-Undang No. 36 tahun 2009 Pasal 171 tentang kesehatan, dimana pemerintah harus mengalokasikan minimal 5 persen dari APBN dan pemerintah daerah provinsi, kabupaten-kota mengalokasikan minimal 10 persen APBD untuk anggaran kesehatan. Besaran anggaran kesehatan yang dimaksud tersebut diprioritaskan untuk kepentingan pelayanan publik yang besarannya sekurangkurangnya 2/3 (dua pertiga) dari anggaran kesehatan dalam APBN maupun APBD.

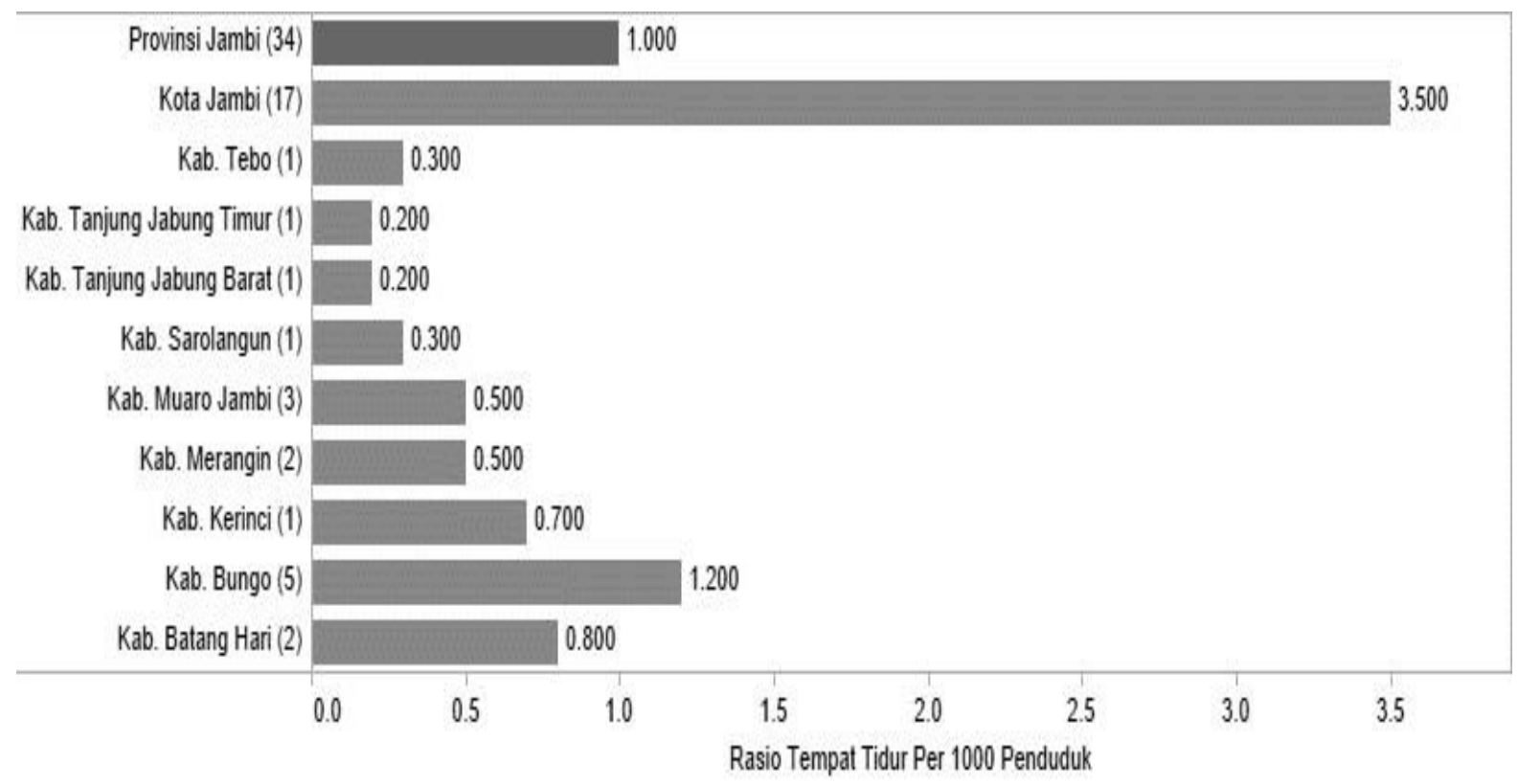

Gambar 1. Jumlah rumah sakit dan rasio tempat tidur per 1000 penduduk kabupaten/kota di provinsi jambi

Ditinjau dari fasilitas kesehatan di Kabupaten/Kota Provinsi Jambi masih terjadi perbedaan yang sangat jauh. Setengah dari rumah sakit yang ada di Provinsi Jambi terdapat di Kota Jambi. Sedangkan daerah dengan jumlah rumah sakit peringkat kedua terbanyak adalah Kabupaten Bungo yang berjumlah 5 buah. Perbedaan jumlah rumah sakit juga mempengaruhi rasio tempat tidur terhadap penduduk. Kota Jambi memiliki rasio tertinggi dimana terdapat 3.5 tempat tidur per 1000 penduduk. Perbedaan fasilitas rumah sakit Kabupaten/Kota di Provinsi Jambi juga mempengaruhi pelayanan kesehatan masyarakat di daerah tersebut. Dikhawatirkan jika terdapat individu yang mengalami penyakit yang pengobatannya menggunakan fasilitas yang lebih baik harus dirujuk ke Kota Jambi.

Menurut Todaro dan Smith (2012) menjelaskan bahwa indikator kesehatan yang umum digunakan adalah angka harapan hidup. Harapan hidup di Provinsi Jambi selalu meningkat setiap tahun. Harapan hidup Provinsi Jambi di tahun 2012 adalah 70.35, 2013 sebesar 70.35, 2014 sebesar 70.43, 2015 sebesar 70.56, 2016 sebesar 70.71 (Kementerian Kesehatan, 2018). Namun, Kabupaten/Kota di Provinsi Jambi masih memiliki harapan hidup dibawah nasional. Tahun 2017 hanya terdapat dua daerah yang memiliki harapan hidup diatas nasional, yaitu Kota Jambi sebesar 72.33 dan Kota Sungai Penuh sebesar 71.71 . 
Berdasarkan Gambar 2 tentang hubungan pengeluaran kesehatan dan angka harapan hidup Kabupaten/Kota di Provinsi Jambi, menjelaskan bahwa terdapat trend positif antara pengeluaran kesehatan dan harapan hidup. Semakin tinggi tingkat pengeluaran kesehatan akan mendorong peningkatan tingkat harapan hidup di Kabupaten/Kota di Provinsi Jambi. Tingkat harapan hidup yang meningkat dan optimal dapat diperoleh dengan menggunakan pengeluaran kesehatan secara efisien.

Menurut Sihaloho, dkk (2019) harapan hidup juga dapat dimaksimalkan jika pemerintah mulai memperhatikan dengan serius tingkat kesehatan masyarakat sejak masa bayi(Sihaloho, Rijoly, and Siregar 2019). Indikasi belum maksimal pelayanan dan kualitas kesehatan tercermin dari kasus kematian bayi. Kota Jambi sebagai pusat pemerintahaan provinsi memiliki anggaran kesehatan tertinggi diantara daerah lain. Tahun 2017, alokasi anggaran kesehatan Kota Jambi sebesar 246 miliar rupiah (Kementerian Keuangan, 2018). Kabupaten Bungo berada di peringkat kedua dengan anggaran 238 miliar rupiah pada tahun 2017. Kabupaten Tanjung Jabung Barat memiliki anggaran kesehatan terkecil sebesar 62 miliar rupiah pada tahun 2017.

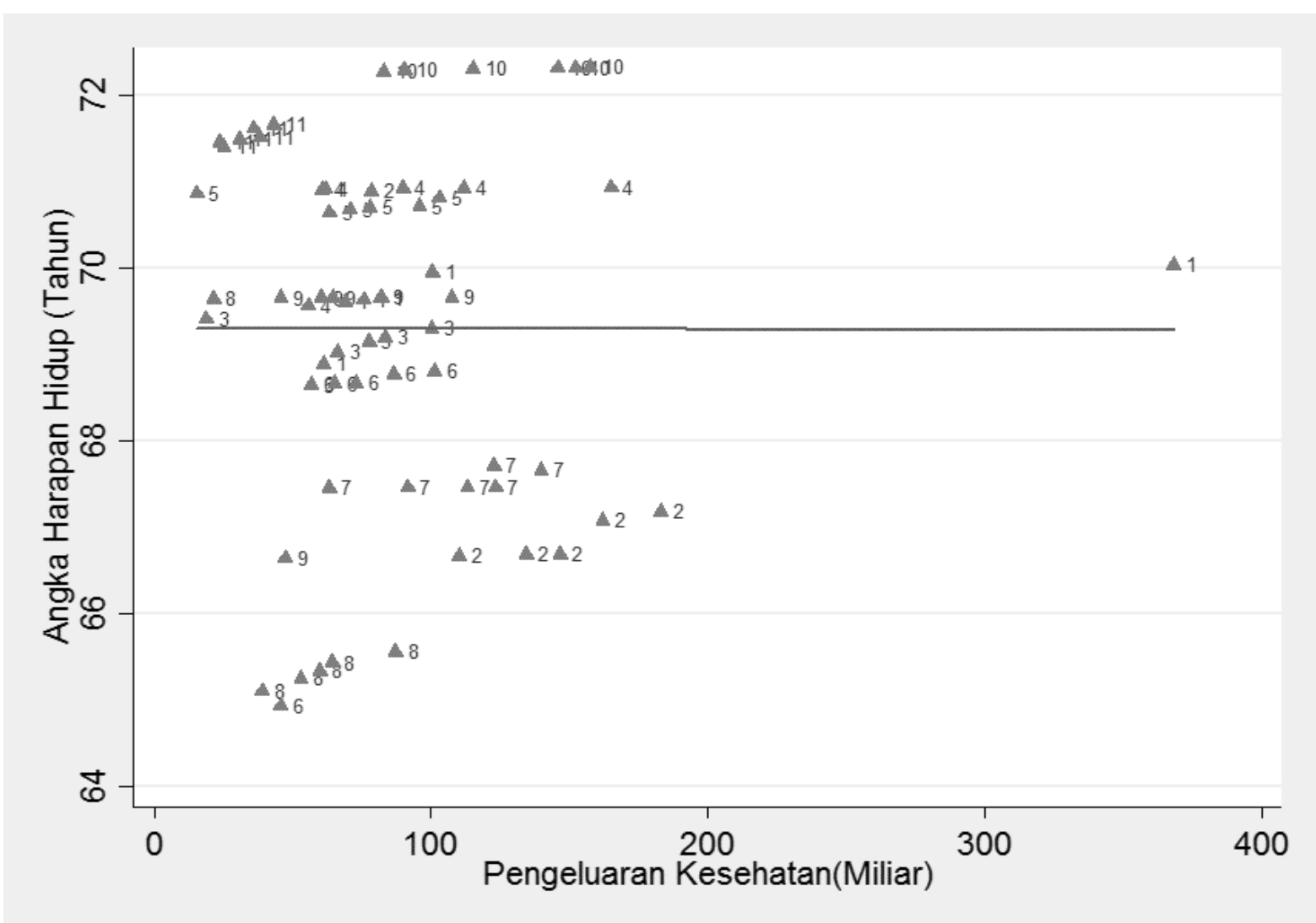

Gambar 2. Hubungan pengeluaran kesehatan dan angka harapan hidup kabupaten-kota di provinsi jambi 2011-2016

Pemerintah daerah melakukan berbagai cara untuk meningkatkan kualitas kesehatan di provinsi Jambi. Salah satu pemerintah daerah adalah meningkatkan alokasi anggaran kesehatan. Peningkatan anggaran kesehatan diharapkan dapat meningkatkan kualitas layanan kesehatan dan kualitas kesehatan masyarakat Provinsi Jambi. Namun, terjadi perbedaan alokasi anggaran kesehatan yang cukup signifikan antar daerah. Selain itu juga hanya dua daerah yang memiliki harapan hidup diatas nasional.

Informasi kesehatan merupakan turunan dari fungsi produksi kesehatan (Halicioglu, 2011). Fungsi produksi kesehatan menjelaskan hubungan atau alur inputs dan alur outputs selama periode tertentu. Output merupakan perhitungan status kesehatan seperti angka harapan hidup dan angka kesakitan. Sedangkan input adalah perlindungan kesehatan, pengeluaran dibidang kesehatan, lingkungan, pendidikan, gaya hidup, faktor genetik, dan lain-lain. Grossman (1972) memberikan konsep model kesehatan dengan gambaran individu sebagai produsen kesehatan. Kesehatan suatu individu berdasarkan pilihan perilaku individu itu sendiri. Namun, individu memiliki batasan dalam 
melaksanakan kehidupan yang lebih sehat karena beberapa alasan seperti; batasan keuangan, keterbatasan kesehatan fisik dan mental, serta lingkungan sosial dan alam.

Pengeluaran pemerintah adalah salah satu alat untuk meningkatkan kualitas sumber daya manusia dalam kesehatan, pendidikan, dan pendapatan (Ouertani dkk, 2018). Sebagai salah satu input dari indikator kesehatan, alokasi anggaran kesehatan harus diukur tingkat efisiensi untuk melihat sejauh mana pengaruhnya terhadap output kesehatan (Ulrike dkk, 2008). Selain itu, pengukuran tingkat efisiensi bertujuan sebagai saran dan masukan untuk pengambil kebijakan (Gupta \& Verhoeven, 2001).

\section{METODE}

Penelitian ini menggunakan Data Envelopment Analysis (DEA) dan regresi Tobit. DEA digunakan untuk melihat tingkat efisiensi dari pengeluaran kesehatan. Sedangkan regresi Tobit digunakan untuk melihat pengaruh faktor lingkungan terhadap nilai efisiensi. Input yang digunakan dalam analisis DEA adalah pengeluaran kesehatan kabupaten/kota di Provinsi Jambi, sedangkan output dari analisis DEA adalah angka harapan hidup, angka kematian bayi, dan angka kematian ibu. Variabel faktor lingkungan dalam model Tobit adalah jumlah penduduk dan tingkat kemiskinan.

Model DEA yang digunakan berdasarkan Banker, dkk (1984), sebagai berikut:

$\operatorname{Max} \theta \quad(1)$

$$
\begin{aligned}
& \text { Subject to : } \\
& \sum_{j=1}^{n} \lambda_{j} X_{j} i=1,2, \ldots, m \\
& \sum_{j=1}^{n} \lambda_{j} Y_{r j} \leq \theta Y_{r 0} \quad r=1,2, \ldots, S \\
& \sum_{j=1}^{n} \lambda_{j}=1 \lambda_{j} \geq 0 j=1,2, \ldots, n
\end{aligned}
$$

Dimana: $\theta$ adalah nilai efisiensi, input dijelaskan dengan $i$ dan output digambarkan $r$. Sedangkan untuk persamaan Tobit sebagai berikut:

$$
\begin{aligned}
& \boldsymbol{\theta}_{i t}=\boldsymbol{\beta}_{\mathbf{0}}+\boldsymbol{\beta}_{\mathbf{1}} \boldsymbol{P o v}_{\boldsymbol{i t}}+\boldsymbol{\beta}_{2} \boldsymbol{P o p}_{i t}+\boldsymbol{\mu}_{i t} \\
& \text { dimana; Pov adalah jumlah penduduk miskin Kabupaten/Kota di Provinsi Jambi dan Pop adalah } \\
& \text { total penduduk Kabupaten/Kota di Provinsi Jambi }
\end{aligned}
$$

\section{HASIL DAN PEMBAHASAN}

Hasil DEA didapatkan nilai efisiensi di Provinsi Jambi hanya dua Kota yang konstan efisien selama periode 2011 sampai 2016. Perbandingkan antara input dan output dari analisis DEA untuk seluruh daerah di Provinsi Jambi menghasilkan nilai efisiensi yang berbeda setiap tahun. Gambar 3 menjelaskan tentang nilai efisiensi Kabupaten-Kota di Provinsi Jambi tahu 2011 sampai 2016. Tahun 2011, terdapat dua kota dan empat kabupaten dengan nilai efisiensi sebesar 1. Sedangkan daerah dengan nilai efisiensi paling rendah tahun 2011 adalah Kabupaten Muaro Jambi dan Kabupaten Kerinci yaitu sebesar 0.37. Tahun 2012, semua daerah mengalami peningkatan nilai efisiensi, kecuali Kabupaten Tanjung Jabung Barat. Skor efisiensi Tanjung Jabung Barat tahun 2012 turun menjadi 0.40.

Di tahun 2013, terdapat tiga daerah dengan nilai efisiensi tidak mencapai 1. Ketiga daerah tersebut adalah, Kabupaten Kerinci (0.79), Kabupaten Sarolangun (0.91) dan Kabupaten Tanjung Jabung Barat (0.40). Kabupaten Muaro Jambi dan Kabupaten Tanjung Jabung Timur di tahun 2014 mengalami penurunan nilai efisiensi. Kabupaten Muaro Jambi di tahun 2014 memiliki nilai efisiensi sebesar 0.47 atau mengalami penurunan sebesar 52.3 persen, dan Kabupaten Tanjung Jabung Timur sebesar 0.94. Kabupaten Tanjung Jabung Barat ditahun 2014 mengalami peningkatan nilai efisiensi sebesar 17.3 persen atau menjadi sebesar 0.49 .

Daerah terbanyak di Provinsi Jambi dengan nilai efisiensi tidak mencapai 1 terjadi di tahun 2015. Hanya terdapat lima daerah dengan nilai efisiensi sebesar 1. Banyak daerah di tahun 2015 mengalami penurunan nilai efisiensi, seperti Kabupaten Batanghari, Kabupaten Kerinci, Kabupaten Merangin, Kabupaten Tanjung Jabung Barat, dan Kabupaten Tanjung Jabung Timur. Persentase penurunan terbesar terjadi di Kabupaten Merangin yaitu sebesar 54 persen. Hanya satu daerah yang mengalami peningkatan nilai efisiensi di tahun 2015, yaitu Kabupaten Muaro Jambi. Penurunan nilai efisiensi mengindikasikan bahwa banyak kabupaten-kota di tahun 2015 tidak efisien atau optimal dalam alokasi belanja kesehatan. 
Terjadi perbedaan nilai efisiensi yang terlalu timpang antar daerah di tahun 2016. Terdapat tiga daerah di tahun 2016 memiliki nilai efisiensi dibawah 0.5, yaitu Kabupaten Batang Hari (0.13), Kabupaten Bungo (0.19), Kabupaten Merangin (0.23). Kabupaten Merangin mendapatkan nilai terendah selama periode penelitian di tahun 2016. Nilai efisiensi yang rendah di tahun 2016 menjelaskan bahwa ketiga daerah tersebut tidak efisien dalam alokasi belanja kesehatan. Kabupaten Tanjung Jabung Barat di tahun 2016 memiliki nilai efisiensi sebesar 0.51 atau meningkat 64 persen dari tahun sebelumnya. Artinya Kabupaten Tanjung Jabung Barat lebih efisien dalam alokasi belanja kesehatan dibanding tahun sebelumnya.

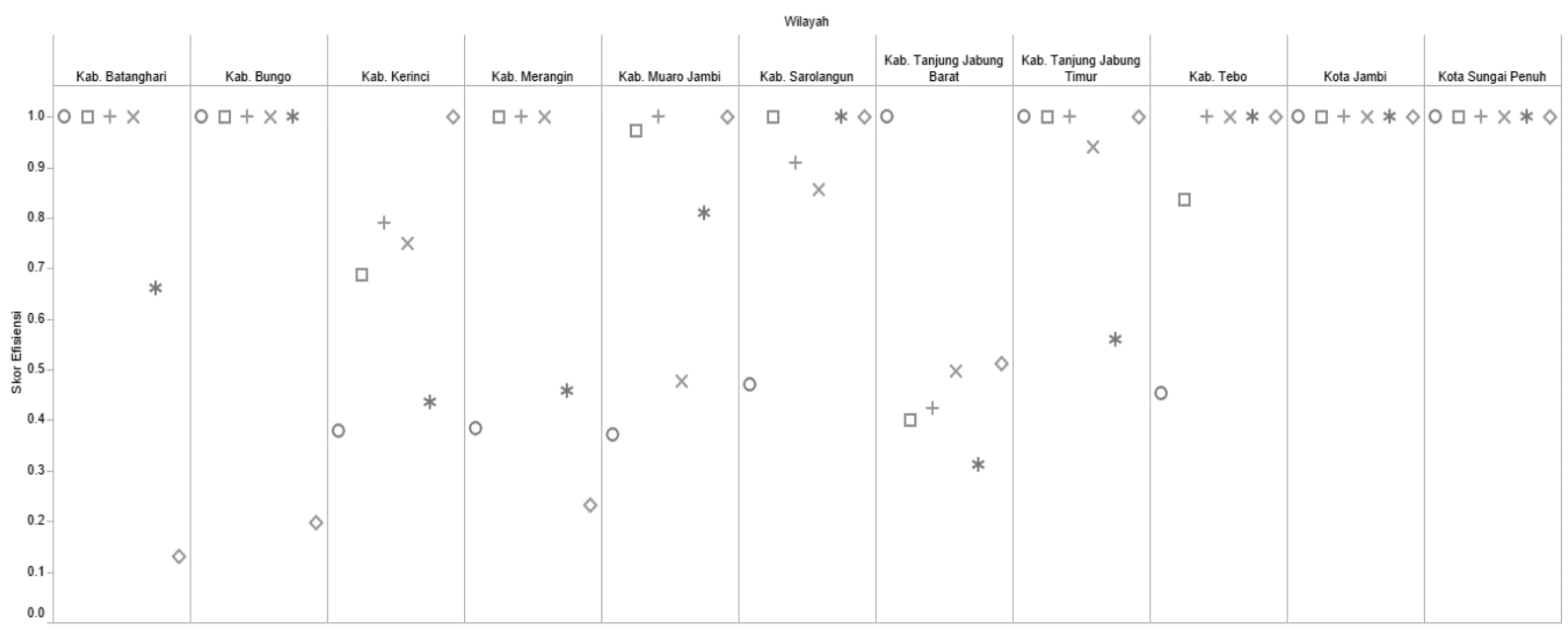

Gambar 3. Skor efisiensi kabupten-kota di provinsi jambi 2011-2016

Kota Jambi dan Kota Sungai Penuh memiliki nilai efisiensi yang konstan selama periode penelitian. Beberapa alasan dua daerah tersebut memiliki nilai efisiensi sebesar 1. Fasilitas kesehatan di Kota Jambi lebih banyak dibanding kabupaten-kota lainnya. Selain itu persentase cakupan kunjungan neonatal (KN1) paling tinggi terdapat di Kota Jambi. Hal ini dikarenakan bayi berumur 0-28 hari sangat berisiko terkena gangguan kesehatan (Dinas Kesehatan Provinsi Jambi, 2016). Kota Sungai Penuh merupakan kota hasil pemekaran di tahun 2009 . Karena jumlah penduduk yang masih sedikit dibanding daerah lain, maka pengeluaran kesehatan masih bisa mengontrol kesehatan secara efisien. Ditambahkan lagi bahwa pelayanan kesehatan ibu hamil sesuai standar (K4) di Kota Sungai Penuh memiliki persentase tertinggi di Provinsi Jambi.

Hasil regresi tobit memperlihatkan pengaruh faktor lingkungan terhadap alokasi pengeluaran kesehatan di Kabupaten/Kota di Provinsi Jambi. Menurut Todaro (2012) penduduk yang tumbuh terlalu cepat memiliki efek negatif bagi kesejahteraan manusia. Maka dari itu banyak negara miskin mencoba mengatur pertumbuhan penduduknya. Banyak wanita di negara berkembang cenderung menikah di usia dini. Hal tersebut dapat mendorong pertumbuhan populasi yang cepat di negara berkembang.

Tabel 1. Hasil regresi tobit

\begin{tabular}{lllll}
\hline & dy/dx & Std.Err & $\mathrm{T}$ & $\mathrm{P}>|\mathrm{t}|$ \\
\hline Pov & -.008839 & .0098954 & -0.89 & 0.375 \\
Pop & .000000785 & 0.00000106 & 0.74 & 0.462 \\
\hline
\end{tabular}

Penduduk yang tumbuh sangat cepat akan berakibat buruk bagi kesehatan. Indikasi tersebut dikarenakan pertumbuhan penduduk yang cepat akan menjadi beban bagi anggaran kesehatan, yang tercermin dari pengeluaran kesehatan per kapita yang semakin kecil. Pemerintah sebagai penyedia layanan publik akan kesulitan dalam memberikan pelayanan kesehatan kepada semua masyarakat. Individu yang hidup didalam kemiskinan akan mudah terkena penyakit dan kekurangan dibanding 
individu yang hidup dengan layak. United Nation tahun 2005 dalam laporannya menjelaskan bahwa kemiskinan identik dengan malnutrisi, buta huruf, layanan kesehatan yang rendah, dan anggota keluarga yang banyak. Ini menunjukkan bahwa kemiskinan akan membuat pemerintah lebih sulit mengatasi masalah kesehatan di semua masyarakat.

Berdasarkan Tabel 1, kemiskinan memiliki efek marginal negatif sekitar -0.008839 terhadap efisiensi anggaran kesehatan dan tidak signifikan. Hal ini mengindikasikan bahwa sejumlah besar orang yang hidup dalam kemiskinan akan menurunkan skor efisiensi. Meningkatnya seribu orang miskin akan menurunkan skor efisiensi sekitar 0.008839. Variabel populasi memiliki efek marginal 0.000000785 terhadap nilai efisiensi alokasi pengeluaran kesehatan di Kabupaten/Kota di Provinsi Jambi. Artinya, setiap penambahan satu penduduk akan meningkatkan nilai efisiensi sebesar 0.000000785. Selama periode penelitian rata - rata pertumbuhan penduduk di Provinsi Jambi tergolong rendah yaitu 1.78 persen. Hasil regresi Tobit yang menjelaskan bahwa populasi searah dengan nilai efisiensi. Hal ini menjelaskan bahwa pengeluaran kesehatan masih bisa mencukupi pelayanan kesehatan Kabupaten/Kota di Provinsi Jambi. Ditambah lagi bahwa nilai efisiensi alokasi kesehatan yang inkonsisten menyebabkan hasil regresi tidak signifikan.

\section{SIMPULAN}

Hasil dari DEA menunjukkan bahwa Kabupaten/Kota di Provinsi Jambi mengalami inkonsisten nilai efisiensi. Hanya terdapat dua daerah yang konsisten dengan nilai sebesar 1 . Hal ini mengindikasikan tidak optimal nya penggunaan alokasi anggaran kesehatan untuk menciptakan output kesehatan yang optimal. Alokasi pengeluaran kesehatan belum sepenuhnya fokus untuk meningkatkan kualitas layanan kesehatan. Pemerintah daerah cenderung meningkatkan anggaran kesehatan untuk pengeluaran rutin seperti upah dan gaji. Selain itu juga pemerintah daerah harus mencoba menggunakan atau mengalokasikan anggaran untuk membangun infrastruktur kesehatan. Pemerintah daerah juga harus membangun fasilitas yang memiliki akses mudah ke masyarakat. Pemerintah provinsi maupun kabupaten/kota juga terus mendorong program kesehatan guna mencapai kesehatan masyarakat yang optimal. Faktor lingkungan juga harus mendapat perhatian pemerintah yang mempengaruhi skor efisiensi. Proses regresi Tobit menunjukkan bahwa efek marginal dari kemiskinan berpengaruh negatif dan tidak signifikan. Sedangkan efek marginal dari populasi berpengaruh positif terhadap nilai efisiensi. Walaupun pengaruh lingkungan selama periode penelitian tidak signifikan, pemerintah harus menyiapkan strategi ketika kemiskinan dan populasi mempengaruhi alokasi kesehatan secara signifikan.

\section{DAFTAR PUSTAKA}

Badan Pusat Statistik. (2018). Jambi Dalam Angka 2018.

Banker, R. D., Charnes, A., \& Cooper, W. W. (1984). Some Models for Estimating Technical and Scale Inefficiencies in Data Envelopment Analysis. Management Science, 30(9), 1078-1092. https://doi.org/10.1287/mnsc.30.9.1078।

Dinas Kesehatan Provinsi Jambi. (2016). Profil Kesehatan Provinsi Jambi 2015.

Grossman, M. (1972). On the Concept of Health Capital and the Demand for Health. Journal of Political Economy, 80(2), 223-255. https://doi.org/10.1086/259880

Gupta, S., \& Verhoeven, M. (2001). The efficiency of government expenditure: Experiences from Africa. Journal of Policy Modeling. https://doi.org/10.1016/S0161-8938(00)00036-3

Halicioglu, F. (2011). Modeling life expectancy in Turkey. Economic Modelling, 28(5), 2075-2082. https://doi.org/10.1016/j.econmod.2011.05.002

Kementerian Kesehatan Republik Indonesia. (2018). Profil Kesehatan Indonesia Tahun 2017.

Ouertani, M. N., Naifar, N., Haddad, H. Ben, \& Zhang, X. (2018). Assessing government spending efficiency and explaining inefficiency scores: DEA-bootstrap analysis in the case of Saudi Arabia. Cogent Economics \& Finance, 6(00), 1-16. https://doi.org/10.1080/23322039.2018.1493666 
Sihaloho, Estro Dariatno, Jacobus Cliff Diky Rijoly, and Adiatma Yudistira Manogar Siregar. 2019.

“Analisis Efisiensi Belanja Kesehatan Provinsi Maluku.” Jurnal Akuntansi dan Ekonomi 4(2): 5867.

United Nation. (2005). Populatin Challenges and Development Goals.

Todaro, Michael P., Smith, Stephen C. (2012). Economic Development 11th Edition. Harlow: Pearson Education Limited.

Ulrike, M., Dierx, A., \& Ilzkovitz, F. (2008). The effectiveness and efficiency of public spending. Economic Papers EU. https://doi.org/10.2765/22776 